\title{
THE IMPACT OF GROSS DOMESTIC PRODUCT ON SMALL \& MEDIUM ENTERPRISES
}

\author{
Hafiz Mohammad Rizwan Rashid and Karim Nooruddin Arbani
}

\begin{abstract}
This study intends to explore an impact of Gross Domestic Product (GDP) on Performance of Small \& Medium Enterprises (SME) in Pakistan. As the Interest and Inflation rate are high, this research has been taken to find the relation between the changes in inflation and interest ad ow they impact the performance of SMEs. Although there are several studies associated with the DV (Small \& Medium enterprises) but the paper is unique as it is (based upon data from Secondary sources of Pakistan where there is a severe lacking of such studies. Data has been collected through Mono method and indicate effect of GDP on Performance of SME). OCDC countries governments are facing the challenges of low growth, weak trade, weak investment and rising high inequality that's why the researcher will investigate that the impact of GDP on Performance of SME is Significant in high interest and inflation rate. Therefore this study as one of the Epistemology / pervasive in nature as the study is potent to increase the knowledge in the area of business as well as foreign direct investors. Although this study is supplemented with some limitation as the data collected from Mono method as an archival strategy from Pakistan. This studies would also help Business sector to manage their Interest rate to attract the foreign direct investors to invest more to increase Gross Domestic Product of Pakistan. The sample size for the study is past 15 years of data from secondary sources in Pakistan and researcher will used CFA and SAM approach by E-Views software has been used for the purpose of data analysis and the major reason for the application of the software is theory building approach associate for finding the relationships between GDP and the Performance of SME. Although the paper is supported by descriptive due to quantitative in nature \& as well as inferential analysis in order to make findings of the study potent and reliable enough. The use of the software indicated that there is a relationship between major IV (Gross Domestic
\end{abstract}


Product) and DV of the study (Performance of Small \& Medium Enterprises) and thus the result is prevalent in identifying the relationship between the variables GDP $(I V)$ \& Performance of SME $(D V)$.

Keywords: Performance of Small \& Medium Enterprises, Gross Domestic Product, Interest Rate, Inflation Rate.

\section{INTRODUCTION}

Gross domestic product (y) is a money related extent of the market estimation of all the last product and adventures made in a specific time period, as often as possible every year. (Gross domestic product is a financial proportion of the market estimation of all the last merchandise and ventures created in a particular timeframe, frequently annually.) GDP (apparent) per capita doesn't, in any case, reflect differentiates in the average expense for essential things and the development paces of the countries; thusly using a reason of Gross local item per capita at obtaining power balance (PPP) is obviously continuously important when taking a gander at desires for ordinary solaces between nations, while Ostensible Gross residential item is progressively useful differentiating national economies on the worldwide market.

The OECD characterizes Gross domestic product as a complete proportion of creation akin to all of the gross qualities enclosed of all dweller and institutional units occupied with generation and administrations additionally to any charges, and fewer any sponsorships, on things excluded from the estimation of their yields.

There is growing identification of the vital role little and medium enterprises (SMEs) play in economic development. The SMEs represent concerning ninetieth of total business units in Gold Coast and account of hr of Ghana's used working class (KDI, 2008).they're usually delineated as economical and prolific job creators, the seeds of massive businesses and also the fuel of national economic engines. Even within the developed industrial economies, it's the SME sector instead of the multinationals that's the most important leader of employees (Mullineux, 1997).this is often conjointly supported by a groundwork done on little businesses within the U.S DR. Charles Ou in June 2006, that indicated that U.S.little businesses numbered twenty three million in 2003 , and it used concerning $1 / 2$ the personal sector men, and conjointly produces concerning $1 / 2$ the nation's personal sector output. in sight of the perennial funding challenge round-faced by these SMEs, several interventions are created by the govt by its recent financial policy and monetary sector reforms. These have considerably inflated banks' disposal 
to the personal sector however restricted access to credit, high interest rates and preventative collateral necessities still create vital constraints to the expansion Access to medium to longterm funding necessary for capital investment remains tight. the basic theme of this paper is to stress that there exists no customary definition of SMEs and the way it are often a downside within the progression of economy. Pakistan economy is associated to nurturing economy for SMEs. Nothing portrays the fact of Pakistani business surroundings higher than the character of its SME sector. So, it is vital to obviously establish completely different classes of SMEs and takes under consideration numerous styles of enterprises (even little native enterprises or partnerships) beneath one definite definition prior to existence there have been drawn-out debates and arguments concerning the key thresholds within the definition of SMEs.

\section{Economic Background of Pakistan}

GDP per capita is the total market values of (final i.e. not intermediate) goods and services produced within nations divided by the total population. Size of Economy of any country is measured through Gross Domestic Products Now-a-days. Indian economy is 9th largest economy in the world by nominal GDP and 3rd largest by PPP (Purchasing Power parity). To knowing the changes in outputs and standard of living of people, GDP and GDP per capita is one of the best measure. Gross domestic product (GDP) is one of the most important concepts for government and decision makers for planning and policy formulation. With the help of GDP, we can find out whether the economy is in recession, depression or boom. GDP is the comprehensive signal of National Income of the nation.(Chavda \& Kumar, 2018)

Many economies find higher inflation as compared with un-employment and remaining of that with low un-employments. as same as some are in a position in which economy is decrease in inflation and maximum decrease in un-employment but increase in unemployment. As the results show that inflation present in some countries differently. The reaction of inflation on unemployment also find properly. A experienced researcher find out these two variables with relation of their economic problems and a discuss inflation reactions with un-employment and their relations. This study would also help to find the accurate issues for the given phenomena and create statements to improve the current era.(Singh R. , 2018) 
Small and medium enterprises (SMEs) present a positive relation with employment and also same as economic development and growth. SME in Japan have huge impact containing 99\% of organizations. (The Information Dissemination and Policy Promotion Division of Japan's Patent Office, 2009). SME performed effectively like 91\% of Standard business and $61 \%$ of work to increase employment rate and also want to increase the GDP of his country example $52 \%$ to $57 \%$. Those countries in which low salary rate like Pakistan, their size of the organization is a reason of miniaturized scale to medium. How can both organizations measure performance consisting of little and medium based. Flaws of SMEs does not mean error in performance. Its only measure through their financial performance. Effective use of its resources said by new research scholarly exertion will differentiate the monetary administration rehearses reactions on the benefit of SMEs as well as cost effect of office. Main reason of well managed organizations depends on their administration that will help to better in improvement of the presentation and get a maximum profit of business. Also focus on administrative problems. Administration is directly linked with proprietor to look after the performance of supervisor in an effective manner.(Muneer, Ahmad, \& Ali, 2017).

The Pakistan economy is considered as an economy of small and medium enterprises just because of $90 \%$ of businesses are engaged in the Small and medium enterprises which play intense role in boosting the economic growth (Shaikh \& Khoso, 2019b). The Pakistan manufacturing sector has a greater contribution of $13.20 \%$ in the GDP of Pakistan through producing \& delivering qualitative goods to foreign countries. Moreover, it provides a significant employment to labor force, which helps in improving the standard of living of the country peoples and brings prosperity in the national economy. According to SMEDA (Small \& Medium Enterprises Development Authority) the SMEs in Pakistan are mostly engaged in the industrial sector which has frequent focus by the Government to boost up the economy and also have an important role through creation of employment and to bring the economic prosperity in the country. The SMEs also considering as a road map for the economic growth of Pakistan through its vital importance in the national economy (Chughtai \& Alam, 2014).

\section{PROBLEM STATEMENT}

The study revolves around the previous findings such as an analyses of the Impact of Gross Domestic Products (GDP) on Stock Market Returns in India (Chavda \& Kumar, 2018), Study by Shaikh, Kashif and Shaikh (2017), on stock market predictability in Pakistan, and another study which found the impact of GDP and Inflation on Unemployment Rate as a Study of 
Indian Economy in 2011-2018 (Singh, 2018). Another investigation portray that the Impact of GDP, Inflation, Interest and Exchange pace of GDP on Stock market in Zambia (Shula, 2017). A few specialists break down the effect on SMEs in which (Imran, Abdul Hamid, and Aziz, 2018) discover an effect of all out quality administration on trade execution of SMEs Evidence from Manufacturing area from Pakistan. Another scientist checked the connections between money related administration rehearses on productivity of little and medium undertakings with the arbitrator impact of office cost on this relationship (Munir, 2017). Another investigation characterized that An Exploratory Evidence of the Type of Challenges and Opportunities Perceived by the Small and Medium Enterprises (SMEs) in the Apparel Export Sector of Pakistan (Khan, 2017). Some remote analyst dissects the effect of mechanical advancement on SME's productivity in Nigeria (Adepoju, Olomu, and Akinwale, 2017). Another Pakistani analyst fined a relationship as a Small and Medium Enterprises as Engine in Economic Growth of Pakistan (Chughtai and Alam, Small and Medium Enterprises as Engine in Economic Growth of Pakistan, 2014). Another specialist dissects the effect of Financial Constraints on the Performance of SMEs "A Study of Sindh Province" (Shaikh \& Khoso, 2019a). After the analysis of these impacts, our study is to find the Effect of Gross Domestic Product (GDP) on performance of SMEs Sector in Pakistan.

\section{RESEARCH OBJECTIVE}

The objective of this research is to find out the effect of Gross Domestic Product (GDP) on Performance of Small and Medium Enterprises in Pakistan through Secondary data of Variables.

\section{HYPOTHESIS}

Ho $=$ There is no significant impact of Gross Domestic product (GDP) on Performance of Small and Medium Enterprises (SME) in Pakistan.

$H 1=$ There is a Significant impact of Gross Domestic Product (GDP) on Small and Medium Enterprises (SME) in Pakistan.

\section{THEORETICAL FRAMEWORK}

Theoretical framework describes the combined set of theories who define how the phenomena performed (Svinicki, 2010). This is used for clear the concepts and reasons of relation of these variables and explain the result of study through interpretation. The theoretical framework of 
this research comprises of theories of Gross domestic product (GDP) and Small and Medium Enterprises (SME's) in Pakistan. The researcher select these theories because they will aid in answering the core research question and provide a deeper understanding of the subject study. The knowledge derived from the theoretical framework is going to be applied to the empirical part of the research by designing and executing the research methods used in the research. Therefore, in order to provide knowledge about the impact of Gross domestic product (GDP) has a significant or not significant impact on Performance of Small and Medium Enterprises in Pakistan.

\section{RESEARCH MODEL}

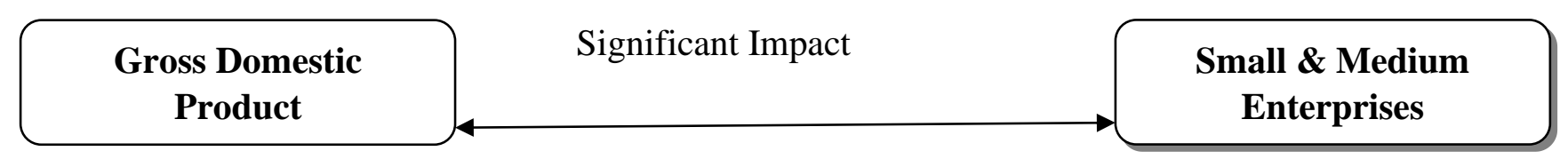

No Significant Impact

\section{SIGNIFICANCE OF THE RESEARCH}

The national income and product accounts (NIPA) allow policymakers, economists and business to analyze the impact of such variables as monetary and fiscal policy, economic shocks such as a spike in oil price, as well as tax and spending plans. This study also helps to increase the value of SME as related with Big Enterprises as a result SME focus their efforts on creating new products and services, thus being capable to adapt their production faster to the changing market requirements. This also helps for SME to continue to survive in a competitive economic environment.

\section{LITERATURE REVIEW}

The job of little and medium business in nations' fares can't be ignored. To trade, any nation depends on little and enormous company's interest. As per Dar et al. (2017) nation fares can be improved through enormous investment of SMEs. Especially, SMEs are anything but difficult to begin the business, require low capital and simple to oversee. These attributes are picking up nations expectation to grow increasingly little and medium business, which are gainful for nation's fares (Rehman, 2016). China expanded the fare volume through the enormous interest of little and medium business and has become the greatest exporter on the planet (Muller et al., 
2015). The investment of Pakistan's SMEs in sends out is low which is $30 \%$ in GDP and 25\% in nation's fares (Yoshino and Wignaraja, 2015). Be that as it may, this commitment is low contrasted and a provincial contender, for example, India (37.5\%) and behind from China's $(60 \%)$ and Japan's (55\%). Declining in sends out causing exchange shortfall and inability to satisfy exchange standards and it is currently turning into a weight on the economy (Hamza, 2016; Munir, 2016). Pakistan SMEs have a potential and chances to improve their exhibition (Nation, 2016). In addition, Government of Pakistan has been making need strides for the advancement of SMEs, they trust SMEs can possibly accomplish the nation's most elevated fare target strategic 2025, it evaluated around 30 billion USD sends out every year (LCCI, 2017). At present, Pakistan's all out fare is FY 2016 \$ 17.32 billion which is low contrasted and earlier years, for example, in FY 2014 fares which was recorded as 21.21 \$ billions and in FY 2015 it dropped to \$ 19.55 billion, and further diminished in FY 2016, which was the most reduced in Pakistan history of current time (PBS, 2016). (Imran, Abdul Hamid, \& Aziz, 2018). In an examination directed by Beck and Demirguc-Kunt (2006), on exploring the imperatives hampering company's development execution found that the financing hindrances are powerfully corresponded with the company's age, size, and sort of proprietorship. Also, Leaven and Woodruff (2007) found that financing limitation has been set apart as the most extreme development hindrance for SMEs in the creating scene. This self-revealed view of financing requirement as a serious development obstruction has additionally been for all intents and purposes approved by the creators. Banerjionee and Duflo (2004), overviewed 253 SMEs in India which acquired an advance at government financed loan cost. The overview found that the size of the advance was legitimately corresponding to the expansion in deals volume of the borrower SMEs which demonstrates that offered access to sponsored financing cost credit, SMEs indicated vigorous development and proposes that already those SMEs have been monetarily compelled. In particular the consequences of world's business condition review (1999-2000) led in 80 nations with an example size of 10,000 firms indicated that the organizations which announced access to financing as an extreme limitation has encountered a moderate yield development (Beck, Demirguc-Kunt, and Levine, 2005). A lot of the observational writing on the investigation of financing requirements has inferred that SMEs face financing hindrances as a result of organization issue and lopsided data among banks and the little firms (Blundell, Dearden, and Meghir, 1996; Bond, Harhoff, and Van Reenen, 1999; Shaikh \& Khoso, 2019a) 
Pakistan situated in South Asia, with populace of 188 million and DGP rate $4.7 \%$ (The World Bank, 2015). Exchange and business assumed a significant job being developed of the economy with the goal that the administration of Pakistan has set up a body for help and advance this area. This administration body is called Small and Medium Enterprises Development Authority (SMEDA) and it has duty of strategies making identified with advancement of SMEs, assistance of financing is additionally the obligation of SMEDA. It additionally helps in preparing and teaching to the business people. Pakistan's position is least on the off chance that it contrasted and other South Asian nations. The proportion of new firm in Pakistan is low and close contenders of the organizations are India and Bangladesh. Other part, nations of Organization for Economic Co-activity and Development (OECD) performing much better. In particular, United Kingdom (UK) is performing magnificent and got the situation at top of the positioning table. There are numerous elements which are gravely influenced execution of Pakistan organizations, and in such manner independent companies can assume crucial job to improve the Pakistan economy. Presently Pakistan has additionally got participations of OECD. In Pakistan the business visionaries are not quite the same as the business people in different nations. Ali et al. (2010) has revealed the effect of culture of Pakistan on innovative expectations. By utilizing Hofstede's measurements about social, the outcomes demonstrate that components of culture for example; community and vulnerability evasion are gravely influencing the considering enterprising aims in Pakistan. (Muneer, Ahmad, \& Ali, 2017).

\section{GDP}

Zafar and Mustafa (1998) demonstrate a measurably positive connection between large scale factors for the financial development of the Indian economy. They find that spending deficiency contrarily influences the GDP of the economy and simultaneously it impacts decidedly the swelling of the economy. The examination study looks at the private and open ventures raises control on the expansions and business openings that guide esteems as a control system for joblessness. Consequently it is discovered that monetary flourishing ascents with appropriate rules, supporting procedures, and viable activities for the improvement and control of expansion and for the control of joblessness (Kemal, 1989). Zenneth (2007) examines the economy of Nigeria. He finds that joblessness lightening impacts financial factors such swelling, deficiency economy, joblessness low GDP development rate. A similar report analyzes job of financial arrangement in mitigating GDP is the total of the estimation of the considerable number of items delivered in a nation during monetary year. It is discovered one 
of the markers of the creation and development pace of the economy and assume a vital job being developed, business and the equalization of installment (Volker, 2005). ). (Singh R. , 2018)The decisive result of the examination study is that swelling is found as unimportantly powerful for GDP and joblessness with negative relationship.

The presence past writings that examined the linkage between banking part improvement and monetary development are affirmed that the directional connection among financing and monetary development is critical and positive. McKinnon (1973) accepts that an increments in banking administrations and money related exercises are quickening economy toward development. Also, King and Levine (1993) contended that giving more assets to the economy invigorates the development of monetary wheels. In any case, Demetriades and Hussein (1996) tried the causality between money related advancement and development crosswise over 16 creating nations. They found that there is no important connection between money related advancement and financial development. Likewise, Miwa et al (2000) investigated the job of national puts money on creating Japanese economy. (Abusharbeh, 2017)

The directional relationship among financing and monetary development has affirmed the noteworthy and positive connection between banking area advancement and monetary development. Existing writing has bolstered the linkage between banking part improvement and financial development. The stock driving speculation was coherently contended out by McKinnon (1973) and Shaw (1973) that affirms the quickening impact of the advancement of banking administrations and money related exercises on financial development. In 1993, King and Levine has played out an investigation and found that money related markets, particularly banks assume a huge job in the development of genuine economy by giving required assets regarding credit to business people to back venture which animate the development of financial exercises. By the by, utilizing information of sixteen creating nations in 1996 Demetriades and Hussein found the causal connection between budgetary advancement and monetary development yet contended no important relationship. Similarly, Miwa et al (2000) investigated that the Japanese economy built up their own store of assembling firms through decentralized and focused capital markets instead of bank credits supply. Utilizing information from creating and mechanical nations Calderon and Liu (2003) found bidirectional causality between money related advancement and monetary development and they recommended that over extensive stretch of time budgetary profundity has critical commitment through the causal relationship in the creating nations. (Ahmed, Yousuf, \& Lubna, 2019) 


\section{RESEARCH METHODOLOGY}

The aim of the study is to find out the Effect of gross domestic product (GDP) on performance of Small and medium Enterprises in Pakistan. The study based on Epistemology because this study increases the knowledge of Business. This study is descriptive due to Quantitative in nature and the archival strategy is implemented because researcher finds a relationship through secondary data testing of both variables. The research approach is transudative due to single Independent and Dependent variable take place. The method of the data collection is Mono because all relevant data collected through single method and the time horizon of Data analysis is Panel Data because in this research data both longitudinal and cross-sectional time horizon take place. Testing can be done through E-Views because of secondary data for getting better result of our research.

\section{Testing Through E-Views}

\begin{tabular}{|c|c|c|c|c|}
\hline Variable & Coefficient & Std. Error & t-Statistic & Prob. \\
\hline$\stackrel{\mathrm{C}}{\mathrm{GDP}}$ & 61844667 & $\begin{array}{r}47465165 \\
201277\end{array}$ & $\begin{array}{r}1.302949 \\
3188245\end{array}$ & $\begin{array}{l}0.2152 \\
0.0071\end{array}$ \\
\hline & & \multicolumn{2}{|c|}{ Mean dependent var } & \\
\hline $\begin{array}{l}\text { R-squared } \\
\text { Adjusted R-squared }\end{array}$ & $\begin{array}{l}0.438806 \\
0.395638\end{array}$ & \multicolumn{2}{|c|}{ S.D. dependent var } & $\begin{array}{l}1.97 \mathrm{E}+08 \\
1.05 \mathrm{E}+08\end{array}$ \\
\hline S.E. of regression & 81619687 & \multicolumn{2}{|c|}{ Akaike info criterion } & 39.39660 \\
\hline Sum squared resid & $8.66 \mathrm{E}+16$ & \multicolumn{2}{|c|}{ Schwarz criterion } & 39.49101 \\
\hline Log likelihood & -293.4745 & \multicolumn{2}{|c|}{ Hannan-Quinn criter. } & 39.39560 \\
\hline F-statistic & 10.16491 & \multicolumn{2}{|c|}{ Durbin-Watson stat } & 1.290838 \\
\hline Prob(F-statistic) & 0.007127 & & & \\
\hline
\end{tabular}

\section{Interpretation}

As we can interpret that $\mathrm{R}$ Values shows moderate Relationship of $43.88 \%$ between our independent and dependent variable. Furthermore R2 values Shows 39.56\% variation in dependent variable due to our independent variable. Our Independent variable (Gross Domestic Product) has a significant impact with Dependent variable (Performance of Small \& Medium 
Enterprises) because of reject the null Hypothesis (T value Greater than 2 \& P value Less than 0.05 ) so the result is Full mediation take place between both Variables.

\section{CONCLUSION}

This study proved that the gross domestic product have a significant impact on dependent variable performance of SMEs in Pakistan. It means that our study reject the null hypothesis which is no significant impact of GDP on Performance of SME in Pakistan and accept the alternative which is a Significant impact of GDP on performance of SME in Pakistan due to results in which "T value" Greater than $2 \&$ "P value" Less than 0.05 . The final result is Full mediation take place between both variables. 


\section{REFERENCES}

Abusharbeh, M. T. (2017). The Impact of Banking Sector Development on Economic Growth: Empirical Analysis from Palestinian Economy . Journal of Emerging Issues in Economics, Finance and Banking (JEIEFB) , 06 (02).

Adepoju, A. O., Olomu, M. O., \& Akinwale, Y. O. (2017). THE IMPACT OF TECHNOLOGICAL INNOVATION ON SME'S PROFITABILITY IN Nigeria. Int. J. Research, Innovation and Commercialisation , 1.

Ahmed, R., Yousuf, M., \& Lubna, N. A. (2019). Banking Sector Development and Economic Growth in Bangladesh: An Empirical Analysis. Canadian Journal of Researcher's Society , 09 (01).

Chavda, K. N., \& Kumar S., T. M. (2018). Analysis of Impact of Gross Domestic Products (GDP) on Stock Market Returns in India. IJCRT , 6 (2).

Chavda, K. N., \& Kumar S., T. M. (2018). Analysis of Impact of Gross Domestic Products (GDP) on Stock Market Returns in India. IJCRT , 6 (2).

Chughtai, M. W., \& Alam, I. (2014). Small and Medium Enterprises as Engine in Economic Growth of Pakistan. Research Journal of economics and business studies , 3 (10).

Chughtai, M. W., \& Alam, I. (2014). Small and Medium Enterprises as Engine in Economic Growth of Pakistan: An Empirical Analysis. Research Journal of Economics and Business Studies , 3 (10).

Goodwin, S. T. (2012).

Imran, M., Abdul Hamid, S. b., \& Aziz, A. b. (2018). The influence of TQM on export performance of SMEs: Empirical evidence from manufacturing sector in Pakistan using PLSSEM. Management Science Letters , 483-496.

Imran, M., Abdul Hamid, S. N., \& Aziz, A. b. (2018, March 16). The influence of TQM on export performance of SMEs: Empirical evidence from manufacturing sector in Pakistan. School of Business Management, Universiti Utara Malaysia, Sintok, Malaysia .

Khan, M. J. (2017). An Exploratory Evidence of the Type of Challenges and Opportunities Perceived by the Small and Medium Enterprises (SMEs) in the Apparel Export Sector of Pakistan. Abasyn Journal of Social Sciences , 10 (2). 
Muneer, S., Ahmad, R. A., \& Ali, A. (2017). Impact of Financial Management Practices on SMEs Profitability with Moderating Role of Agency Cost. Information Management and Business Review , 9 (1), 23-30.

Munir, S. (2017, April). Impact of Financial Management Practices on SMEs Profitability with moderating role of agency cost. Research gate .

Shaikh, A. S., Kashif, M., \& Shaikh, S. (2017). Measuring Stock Market Predictability With Implications Of Financial Ratios: An Empirical Investigation Of Pakistan Stock Market. Journal of Business Strategies, 11(1), 41.

Shaikh, S., \& Khoso, I. U. (2019a). Impact of Financial Constraints on the Performance of SMEs - A Study of Sindh Province. JISR-MSSE, 17 (1).

Shaikh, S., \& Khoso, I. U. (2019b). Corruption-A Grease on Wheels or an Obstruction for SMEs in Developing Economies. Pakistan Journal of Criminology, 11(1).

Shula, K. (2017, April). Impact of GDP, Inflation, Interest and exchange rate of GDP on Stock market in Zambia. Research gate .

Singh, D. R. (2018). Impact of GDP and Inflation on unemployement rate. International journal of management, IT and Engineering, 8 (3).

Singh, R. (2018). Impact of GDP and Inflation on Unemployment Rate. International Journal of Management, IT \& Engineering, 8 (3). 